The Agriculturists 13(1): 101-108(2015) ISSN 2304-7321 (Online), ISSN 1729-5211 (Print)

\title{
Effect of Banana Extract on Growth and Development of Protocorm Like Bodies in Dendrobium sp. orchid
}

\author{
M. Obaidul Islam*, Md. Serazul Islam and Md. Abu Saleh \\ Department of Crop Botany, Bangladesh Agricultural University, Mymensingh - 2202 \\ *Corresponding author and Email: obaidul7_mo@yahoo.com
}

Received: 18 February $2015 \quad$ Accepted: 06 June 2015

\begin{abstract}
An experiment was carried out in Plant Tissue Culture Laboratory, Department of Crop Botany, Bangladesh Agricultural University, Mymensingh to investigate the effect of banana extract on micropropagation of Dendrobium sp. var. Sonia orchid through PLBs. The experiment was conducted during July 2012 to October 2013. Half-Murashige and Skoog (1/2MS) medium were used as basal medium and the medium was supplemented with banana extract at 12.5, 25, 50,100, and $200 \mathrm{ml} \mathrm{L}^{-1}$ with a control, where no banana extract was supplemented. The cultures were done in $100 \mathrm{ml}$ conical flasks and maintain at $25^{\circ} \mathrm{C}$ with $30 \mu \mathrm{mol} \mathrm{m}{ }^{-2} \mathrm{~S}^{-1}$ lighting provided by florescent tubes for 16 hours per day. Banana extract showed significant effect on growth and development of PLBs. Among the treatments, $100 \mathrm{ml} \mathrm{L}^{-1}$ banana extract enhanced new PLBs regeneration from explanted PLBs and growth and development of PLBs. Present research indicated that nutrient requirement for PLBs multiplication and plantlets growth of Dendrobium orchid is quantitatively different in vitro. Finally, $100 \mathrm{ml} \mathrm{L}^{-1}$ and $25 \mathrm{ml} \mathrm{L}^{-1}$ of banana extract may be recommended as supplement into $1 / 2 \mathrm{MS}$ medium for PLBs multiplication and plantlet regeneration, respectively in vitro.
\end{abstract}

Keywords: Banana extract, dendrobium orchid, protocorm like bodies, regeneration

\section{Introduction}

Orchids, the most fascinating and beautiful flower producing plant species belong to the family Orchidaceae. Dendrobium is one of the important orchid species which has long been grown in tropical countries like Thailand, Singapore etc. In many countries orchid industry plays an important role as a source of foreign exchange. Thailand alone exports orchids worth more than 11.4 million US dollar to other countries. The global export value of flower in 1985 was $\$ 1.79$ billion but the value at present is more than $\$ 25$ billion. The environmental condition required for the survival and culture of orchids are adequately available throughout the year in Bangladesh. Therefore, it has a great scope of large scale production of dendrobium orchids to meet the internal demands as well as to earn foreign currency by export. Generally, orchids are propagated through both vegetative and sexual means but the conventional processes are slow and uncertain. Most of the cultivated orchids are found to be self-sterile. The traditional asexual orchid production is extremely slow which can give rise to 2-4 plants per year (Nasiruddin et al., 2003). Asexually, through embryo culture, thousands of plants can 
be propagated within short time in orchid. For mass propagation of orchid in commercial exploitation, millions of plantlets are produced by tissue culture techniques using different plant parts as explants. In tissue culture medium, different growth regulators and some organic compounds (coconut water, tomato and orange juice etc) are frequently used which have regulatory effects on growth and development (Islam and Ichihashi, 1999).

Studies on PLB derived plantlet, production through embryogenesis and the subsequent growth and development of plantlets on medium supplemented with different organic extracts in Dendrobium sp. orchid are scarcely available. A few reports on use of complex organic additives in medium for the growth of PLBs and plantlets regeneration of Phalaenosis sp. is reported by Islam and Ichihashi (1999). Therefore, the present experiment was undertaken to investigate the effect of $\mathrm{BE}$ as supplement into culture medium on regeneration of new PLB, growth of PLBs and PLB derived plantlets of Dendrobium sp. (cv. Sonia) in vitro. The ultimate goal is to enhance growth and development of PLB derived plantlets of Dendrobium sp. orchid to support commercial production. Determination of suitable concentration of extract as supplement into medium and indirectly reduction of cost of the medium were also the objectives of this experiment.

\section{Materials and Methods}

\subsection{Plant materials}

Protocorm like bodies (PLBs) of Dendrobium sp. var. Sonia developed earlier from meristem culture and has been maintained by subculturing bimonthly on fresh medium in the Plant Tissue Culture Laboratory, Department of Crop Botany, Bangladesh Agricultural University (BAU), Mymensingh, were used as plant materials (Figure 1). This experiment was conducted during July 2012 to October 2013 in the same laboratory.

\subsection{Treatments}

Several cultures of PLBs and PLBs derived plantlets were conducted in the experiment. To study the effect on growth and development of PLBs and plantlets 0, 25, 50, 100 and $200 \mathrm{ml} \mathrm{L}^{-1}$ of banana extract were supplemented into culture medium. The experiment was laid out in a Completely Randomized Design (CRD) and each treatment was replicated five times.

\subsection{Culture medium}

Murashige and Skoog (MS, 1962) medium was diluted to half strength (only macro elements) and was used as basal medium for PLB proliferation, plantlet initiation and the subsequent growth and development of initiated plantlets. Five stock solutions namely, macronutrients, micronutrients, Fe-EDTA, vitamins/organics and plant growth regulators were prepared prior to culture medium preparation.

\subsection{Preparation of stock solution of nutrients}

Stock solution of macro-nutrients was prepared 5 times higher than the concentration of medium used in experiment. Five times higher quantity of salt ingredients were taken in $1.0 \mathrm{~L}$ conical flask and dissolved in distilled water, serially by using a magnetic stirrer. Finally, distilled water was added up to the mark. Prepared solution was preserved in a refrigerator at $4^{\circ} \mathrm{C}$ for later use. Similarly, stock solution of micro nutrients (100 times), Fe-EDTA (100 times) and vitamins/organics (100 times) were prepares and stored.

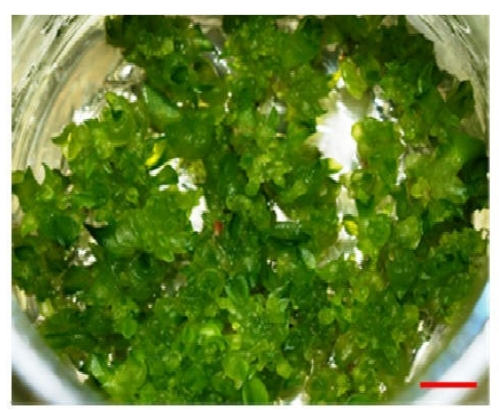

Figure 1. PLBs of Dendrobium sp. var. Sonia. $($ Scale bar $=1.0 \mathrm{~cm})$ 


\subsection{Preparation of banana extract}

The ripe banana (cv. Sagar) was peeled and cut into $1.0 \mathrm{~cm}$ in size and $500 \mathrm{~g}$ of the diced fresh material was boiled for 30 minutes with $500 \mathrm{ml}$ of distilled water and the hot supernatant was filtered through steel mesh $\left(55 \mathrm{~mm}^{-1}\right)$ and adjusted up to $500 \mathrm{ml}$ by adding distilled water.

\subsection{Preparation of medium}

To prepare $1 \mathrm{~L}$ of culture medium sucrose of $20.0 \mathrm{~g}$, macro-nutrients $100 \mathrm{ml}$, micro-nutrients $10 \mathrm{ml}$, Fe-EDTA $10 \mathrm{ml}$ and vitamins $10 \mathrm{ml}$ were mixed in a conical flask with $500 \mathrm{ml}$ distilled water. Myoinocitol $100 \mathrm{mg}$, dissolved in $100 \mathrm{ml}$ distilled water was added to mixture. Different concentration of supplements as mentioned in Tables were added to the solution and mixed thoroughly. The mixture was then made near to $1000 \mathrm{ml}$ by adding distilled water. The $\mathrm{pH}$ of the medium was adjusted to 5.8 by adding of $0.1 \mathrm{~N}$ $\mathrm{NaOH}$ or $0.1 \mathrm{HCL}$ and made up the volume to 1 L. After adjusting the $\mathrm{pH}, 3.0 \mathrm{~g}$ gelrite was added and dissolved by heating in microwave oven. After dispensing the medium the conical were covered with aluminum foils and autoclaved at $121^{\circ} \mathrm{C}$ for 20 minutes under 1.15 $\mathrm{kg} \mathrm{cm}$ of pressure. After cooling at room temperature, the medium was used for culture.

\subsection{Culture of PLBs and plantlets}

The PLBs (100 mg) of similar size were cultured on $30 \mathrm{ml}$ fresh medium supplemented with different concentration of banana extracts following treatments. After 90 days, culture data on new PLBs regeneration and their growth and development were recorded. PLB-derived plantlets were again cultured on same fresh medium supplemented with $1 \mathrm{~g} \mathrm{~L}^{-1}$ of charcoal and after 3 months data were collected. The culture flasks were kept in a growth room and allowed to grow at $25 \pm 1^{\circ} \mathrm{C}$ under 16 hours photoperiod illuminated with fluorescent tube of $30 \mu$ molem $^{-2} \mathrm{~S}^{-1}$. For acclimatization and transplanting in pot, the plantlets were cultured for more than 3.0 months in same fresh medium.

\subsection{Data collection and analysis}

The data on average number of newly regenerated PLBs per flask, number of PLBs, weight per PLB, number of plantlet initiation, weight of plantlets, number of leaf and root per plantlets etc. were recorded after culture. The means were calculated and analyses of variance for all the characters were performed by $\mathrm{F}$ test. The significance of the difference among the pair of means was evaluated by Duncan's Multiple Range Test (DMRT) at 5\% level of significance using MSTAT-C computer programmed.

\section{Results and Discussion}

\subsection{Effects of banana extract $(B E)$ on growth and development of PLBs}

In culture, PLBs regenerated new PLBs and initiated PLB-derived plantlets both in control (free of BE) and banana extract supplemented medium. In control, both PLBs regeneration and plantlet initiation were lower in comparison with that in banana extract supplemented medium. The number of initiated new PLBs was only 86.6 per culture in control condition, where as the numbers were 206.6, 228.6, 554.3 and 514.3, respectively at $25,50,100$, and $200 \mathrm{mlL}^{-1}$ of banana extract supplemented medium (Table 1). Average weight per PLB was significantly higher in control compared to that derived on 100 and $200 \mathrm{mlL}^{-1}$ banana extract supplemented medium.

The total weights of initiated new PLBs were higher with gradual increase of banana extract supplement up to $100 \mathrm{ml} \mathrm{L}^{-1}$ into the medium and then decreased. The number of PLB-derived shoots initiated in banana extract supplemented medium was significantly higher over control. Average PLB-derived shoots in 0.0, 25, 50, 100 and $200 \mathrm{mlL}^{-1}$ of banana extract supplemented medium were 41.6, 56.6, 63.3, 144.0 and 136.0, respectively. The numbers of shoots in banana extract supplemented medium were significantly higher over control. The highest number of shoot 
was obtained in medium supplemented with 100 $\mathrm{ml} \mathrm{L}^{-1}$ of banana extract. Therefore, $100 \mathrm{ml} \mathrm{L}^{-1}$ banana extract as supplement in to medium might be recommend for highest shoot regeneration from PLB in Dendrobium orchid var. Sonia (Table $1 \&$ Figures 2, 3) in vitro.

\subsection{Effects of banana extract on growth and development of shoots}

Growth of shoot in vitro was significantly influenced by banana extract (Table 2, Figures 3, $4,5)$. Different concentration of banana extract enhanced the length of shoots differently. The tallest shoots was $2.8 \mathrm{~cm}$ found in medium supplemented with $25 \mathrm{mlL}^{-1}$ of banana extract into BM, followed by $1.93 \mathrm{~cm}$ at $50 \mathrm{ml} \mathrm{L}^{-1}$ and the shortest shoot was $1.03 \mathrm{~cm}$ found at $200 \mathrm{ml}$ $\mathrm{L}^{-1}$. Number of leaf per plantlet was also the highest at $25 \mathrm{mlL}^{-1}$ of banana extract supplemented into basal medium and followed by control. Similarly, length of leaf, width of leaf, fresh and dry weight of shoots were enhanced significantly over control at $25 \mathrm{mlL}^{-1}$ of banana extract into BM where the higher concentration of banana extract inhibited the growth of leaves (Table 2).

Table 1. Effects of BE on growth and development of PLBs after 90 days culture

\begin{tabular}{|c|c|c|c|c|c|c|}
\hline $\begin{array}{l}\text { Concent. of } \\
\mathrm{BE}\left(\mathrm{ml} \mathrm{L}^{-1}\right) \\
\text { supplemen- } \\
\text { ted }\end{array}$ & $\begin{array}{l}\text { Avg. } \\
\text { number of } \\
\text { new PLBs } \\
\text { culture }^{-1}\end{array}$ & $\begin{array}{l}\text { Avg. } \\
\text { wt. (g) } \\
\text { per new } \\
\text { PLBs }\end{array}$ & $\begin{array}{l}\text { Total wt. } \\
\text { (g) of new } \\
\text { PLBs } \\
\text { culture }^{-1}\end{array}$ & $\begin{array}{l}\text { Avg. num. of } \\
\text { PLB-derived } \\
\text { shoots } \\
\text { culture }^{-1}\end{array}$ & $\begin{array}{l}\text { Avg. wt. (g) } \\
\text { of PLB- } \\
\text { derived shoot } \\
\text { culture }^{-1}\end{array}$ & $\begin{array}{l}\text { Total wt. } \\
\text { (g) of } \\
\text { shoot } \\
\text { flask }^{-1}(\mathrm{~g})\end{array}$ \\
\hline Cont. (0.0) & $86.6 \mathrm{e}$ & $0.019 \mathrm{a}$ & $1.70 \mathrm{c}$ & $41.6 \mathrm{e}$ & $0.029 \mathrm{a}$ & $1.1 \mathrm{c}$ \\
\hline 25 & $206.6 \mathrm{~d}$ & $0.016 \mathrm{a}$ & $2.94 b$ & $56.6 \mathrm{~d}$ & $0.025 b$ & $1.4 \mathrm{~b}$ \\
\hline 50 & $228.6 c$ & $0.014 \mathrm{ab}$ & $2.73 b$ & $63.3 \mathrm{c}$ & $0.025 b$ & $1.5 \mathrm{~b}$ \\
\hline 100 & $554.3 \mathrm{a}$ & $0.008 b$ & $4.48 \mathrm{a}$ & $144.0 \mathrm{a}$ & $0.029 \mathrm{a}$ & $4.0 \mathrm{a}$ \\
\hline 200 & $514.3 b$ & $0.008 \mathrm{~b}$ & $4.19 \mathrm{a}$ & $136.0 \mathrm{~b}$ & $0.028 \mathrm{a}$ & $3.9 \mathrm{a}$ \\
\hline $\mathrm{LSD}_{0.05}$ & 10.41 & 0.005 & 0.481 & 4.88 & 0.002 & 0.128 \\
\hline
\end{tabular}

In a column different letter indicate significant difference at $5 \%$ level of significance.

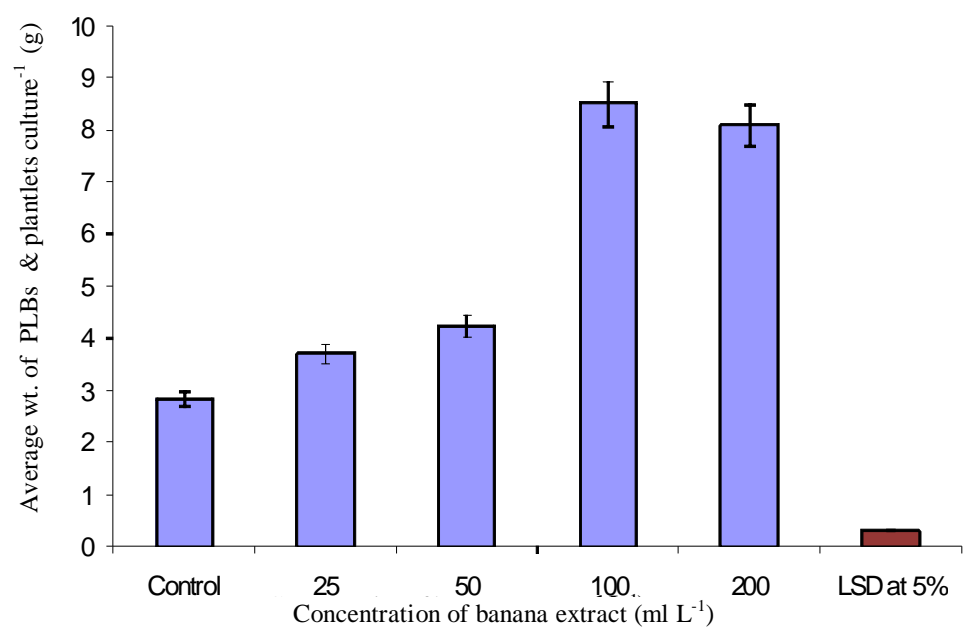

Figure 2. Effects of banana extract in culture medium on growth of PLBs after 90 days (Narrow vertical bars at top of each bar represent STD values) 
Table 2. Effects of BE on growth and development of shoots after 90 days culture

\begin{tabular}{lllllll}
\hline $\begin{array}{l}\text { Con. of BE in } \\
\text { medium } \\
\left(\mathrm{mlL}^{-1}\right)\end{array}$ & $\begin{array}{l}\text { Length of } \\
\text { shoot }(\mathrm{cm})\end{array}$ & $\begin{array}{l}\text { Number of } \\
\text { leaf } \\
\text { plantlet }\end{array}$ & $\begin{array}{l}\text { Length } \\
\text { of leaf } \\
(\mathrm{cm})\end{array}$ & $\begin{array}{l}\text { Width of } \\
\text { leaf }(\mathrm{cm})\end{array}$ & $\begin{array}{l}\text { Fresh } \\
\text { weight of } \\
\text { shoot }(\mathrm{g})\end{array}$ & $\begin{array}{l}\text { Dry } \\
\text { weight of } \\
\text { shoot }(\mathrm{g})\end{array}$ \\
\hline $\begin{array}{l}\text { Control } \\
12.5\end{array}$ & $1.8 \mathrm{~b}$ & $3.6 \mathrm{bc}$ & $1.3 \mathrm{c}$ & $0.66 \mathrm{c}$ & $0.28 \mathrm{bc}$ & $0.014 \mathrm{ab}$ \\
25 & $2.6 \mathrm{a}$ & $4.3 \mathrm{ab}$ & $1.6 \mathrm{~b}$ & $1.03 \mathrm{~b}$ & $0.31 \mathrm{ab}$ & $0.013 \mathrm{ab}$ \\
50 & $2.8 \mathrm{a}$ & $5.3 \mathrm{a}$ & $2.1 \mathrm{a}$ & $1.20 \mathrm{a}$ & $0.34 \mathrm{a}$ & $0.029 \mathrm{a}$ \\
100 & $1.9 \mathrm{~b}$ & $3.3 \mathrm{bcd}$ & $1.2 \mathrm{~cd}$ & $0.50 \mathrm{~d}$ & $0.25 \mathrm{c}$ & $0.012 \mathrm{ab}$ \\
200 & $1.3 \mathrm{c}$ & $2.6 \mathrm{~cd}$ & $1.0 \mathrm{de}$ & $0.36 \mathrm{de}$ & $0.18 \mathrm{~d}$ & $0.011 \mathrm{ab}$ \\
\hline $\mathrm{LSD}_{0.05}$ & $1.0 \mathrm{c}$ & $2.3 \mathrm{~d}$ & $0.8 \mathrm{e}$ & $0.26 \mathrm{e}$ & $0.06 \mathrm{e}$ & $0.007 \mathrm{~b}$ \\
\hline
\end{tabular}

In a column different letter indicates significant difference at $5 \%$ level of significance.

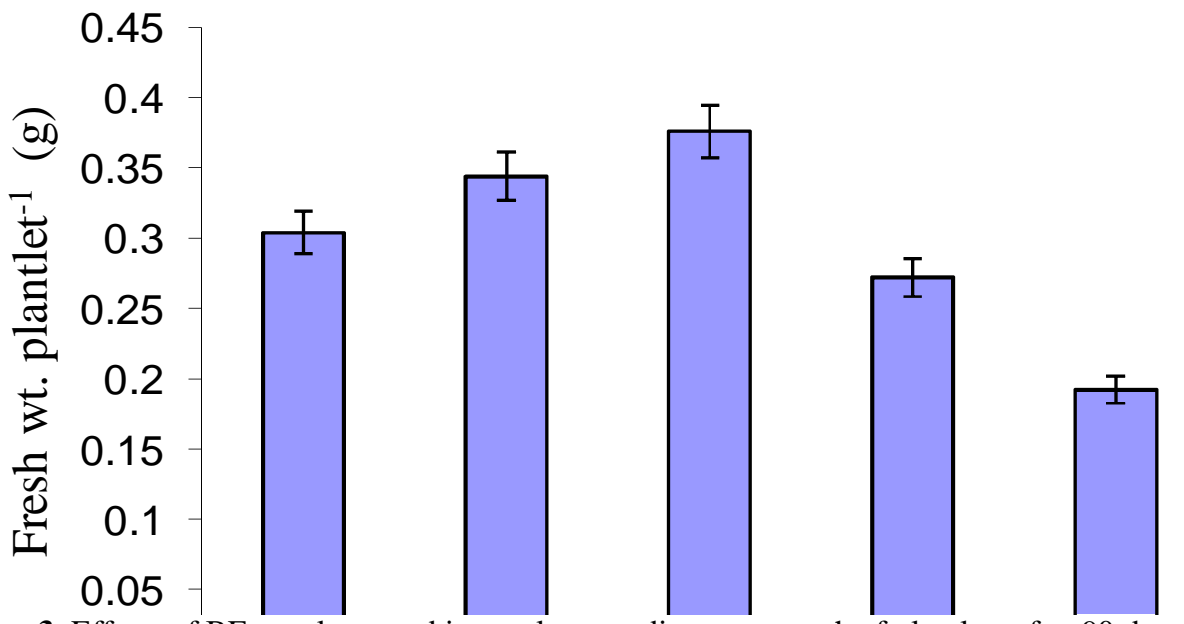

Figure 3. Effects of BE supplemented into culture medium on growth of plantlets after 90 days culture (Narrow vertical bars at top of each bar represent STD values)

\subsection{Effects of $B E$ on growth and development of roots}

Growth of root in vitro was stimulated with BE. The highest number of root was 7.0 plantlet $^{-1}$ recorded at $25 \mathrm{ml} \mathrm{L}^{-1}$ of $\mathrm{BE}$ supplemented into $\mathrm{BM}$ and the lowest number of root was 2.00 plantlet $^{-1}$ at $200 \mathrm{ml} \mathrm{L}^{-1}$ (Table 3). Similar trend for the length of roots was recorded. Among the treatments, $25 \mathrm{ml} \mathrm{L}^{-1}$ of $\mathrm{BE}$ supplemented into $\mathrm{BM}$ showed the longest root of $1.8 \mathrm{~cm}$ and the shortest roots of $0.6 \mathrm{~cm}$ was found at $200 \mathrm{mlL}^{-1}$. Higher or lower concentration of extract in medium decreased the length. Diameter of roots was also enhanced by BE supplemented into $\mathrm{BM}$. The maximum diameter of roots were 0.16 and $0.08 \mathrm{~cm}^{2}$ at $25 \mathrm{ml} \mathrm{L}^{-1}$ and $200 \mathrm{ml} \mathrm{L}^{-1}$ of BE, respectively. Similarly, BE supplemented into basal medium also influenced the average fresh and dry weight of roots. The maximum fresh and dry weight of root plantlet ${ }^{-1}$ was recorded at 0.03 $\mathrm{cm}$ and $0.008 \mathrm{~cm}$, respectively at $25 \mathrm{ml} \mathrm{L}^{-1} \mathrm{BE}$. The lowest fresh weight and dry weight were $0.01 \mathrm{~cm}$ and $0.001 \mathrm{~cm}$, respectively at $200 \mathrm{ml} \mathrm{L}^{-1}$ of BE supplement. 

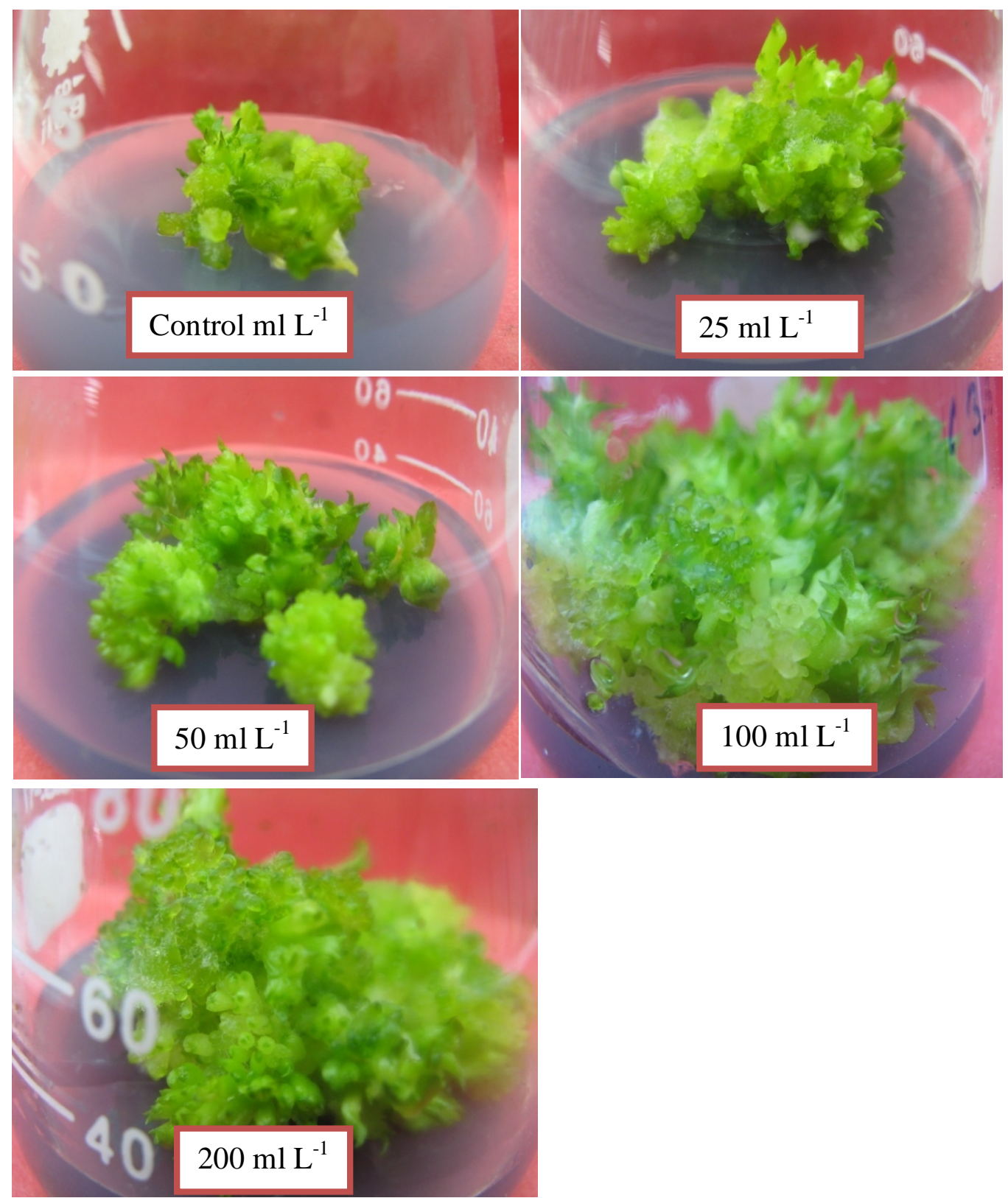

Figure 4. The growth and development of PLBs of Dendrobium orchid var. Sonia in medium supplemented with banana extract at $0.0 \mathrm{ml} \mathrm{L}^{-1}, 25 \mathrm{ml} \mathrm{L}^{-1}, 50 \mathrm{ml} \mathrm{L}^{-1}, 100 \mathrm{ml} \mathrm{L}^{-1}$ and $200 \mathrm{ml}$ $\mathrm{L}^{-1}$ after 90 days culture. Scale bar $=1.0 \mathrm{~cm}$. 


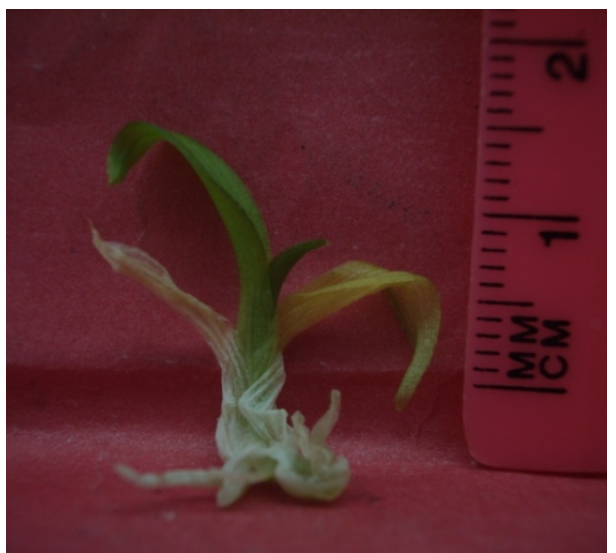

Figure 5. Effects of $\mathrm{BE}\left(25 \mathrm{ml} \mathrm{L}^{-1}\right.$,) on the growth of plantlets after 90 days culture.

Table 3. Effects of BE on growth and development of roots after 90 days culture

\begin{tabular}{|c|c|c|c|c|c|}
\hline $\begin{array}{l}\text { Concentration of BE } \\
\left(\mathrm{mgL}^{-1}\right)\end{array}$ & $\begin{array}{l}\text { Number of } \\
\text { roots } \\
\text { plantlet }^{-1}\end{array}$ & $\begin{array}{l}\text { Length of } \\
\text { roots } \\
\text { plantlet }^{-1}\end{array}$ & $\begin{array}{l}\text { Diameter of } \\
\text { a root }(\mathrm{cm})\end{array}$ & $\begin{array}{l}\text { Fresh wt. } \\
\text { of root }(\mathrm{g}) \\
\text { plantlet }^{-1}\end{array}$ & $\begin{array}{l}\text { Dry wt. of } \\
\text { roots }(\mathrm{g}) \\
\text { plantlet }^{-1}\end{array}$ \\
\hline Control & $5.00 \mathrm{c}$ & $1.60 \mathrm{~b}$ & $0.133 \mathrm{~b}$ & $0.018 \mathrm{ab}$ & $0.006 \mathrm{ab}$ \\
\hline 12.5 & $6.00 \mathrm{~b}$ & $1.73 \mathrm{ab}$ & $0.143 \mathrm{ab}$ & $0.028 \mathrm{ab}$ & $0.007 \mathrm{ab}$ \\
\hline 25 & $7.00 \mathrm{a}$ & $1.83 \mathrm{a}$ & $0.160 \mathrm{a}$ & $0.030 \mathrm{a}$ & $0.008 \mathrm{a}$ \\
\hline 50 & $3.66 \mathrm{~d}$ & $1.40 \mathrm{c}$ & $0.126 b c$ & $0.016 \mathrm{ab}$ & $0.005 \mathrm{ab}$ \\
\hline 100 & $3.00 \mathrm{e}$ & $0.90 \mathrm{~d}$ & $0.103 \mathrm{~cd}$ & $0.012 \mathrm{ab}$ & $0.003 \mathrm{ab}$ \\
\hline 200 & $2.00 \mathrm{f}$ & $0.60 \mathrm{e}$ & $0.080 \mathrm{~d}$ & $0.010 \mathrm{~b}$ & $0.001 \mathrm{~b}$ \\
\hline $\mathrm{LSD}_{0.05}$ & 0.530 & 0.159 & 0.025 & 0.017 & 0.005 \\
\hline
\end{tabular}

In a column different letter indicate significant difference at $5 \%$ level of significance.

In the present experiment, number and weight of new PLBs and plantlet initiation per culture were enhanced with banana extract supplement in medium compared to control. Indicating the beneficial effect of banana extract as supplement into medium on growth and differentiation of PLBs and PLB-derived plantlets in vitro. Similar reports were stated by Chen and Chang (2001) and Arditti (1979). An efficient concentration of $100 \mathrm{mlL}^{-1}$ in $1 / 2 \mathrm{MS}$ medium was fond to be the best as supplement for growth and development of PLBs in terms of new PLBs regeneration. The positive and enhancing effects of banana homogenate $(\mathrm{BH})$ on new PLBs regeneration and development of healthy shoot system (long and robust shoots) from PLBs were attributed earlier by Aktar et al. (2008) in Dendrobium orchid. Similarly, $10 \%$ banana homogenate enhanced leaf size of Spathoglottis kimbal lianaiis (Minea et al., 2004). Banana homogenate significantly increased the number of leaves in Dendrobium nobile cultures (Sudeep et al., 1997). Similar result was also reported by Saranjeet and Bhutani (2012). In the present experiment, a higher concentration of BE $200 \mathrm{mlL}^{-1}$ was inhibitory to regeneration and growth of PLBs and thus indicated supra-optimal. Similarly $25 \mathrm{ml} \mathrm{L}^{-1}$ was optimum for plantlets growth over higher 
concentration. This result is in agreement to the report of Lekha, et al. (2005) in Dendrobium hybrid.

\section{Conclusions}

Organic extracts is a complex substance containing different levels of carbohydrate, amino acids, proteins, vitamins, phenoloc acids and many alkaloid compounds. Any of these component(s) could be responsible for promoting growth and development of the cultures. Which ingredient or ingredients were supportive for growth and development of PLBs or plantlets in vitro are to be clarified by further detail study. However, the present study indicates that nutritional requirement is different in PLBs and PLB-derived plantlets. Finally, it might be concluded that banana extract could help in building an organic medium for in vitro production of Dendrobium orchids.

\section{References}

Aktar, S., Nasiruddin K. M. and Hossain, K. 2008. Effects of different media and organic additives interaction on in vitro regeneration of Dendrobium orchid. Journal of Agricultural and Rural Development, 6: 69-74.

Arditti, J. 1979. Aspects of physiology of orchids. Advances in Botanical Research, 7: 421-655.

Chen, J. T. and Chang, W. C. 2001. Effects of auxin and cytokinin on direct somatic embryogenesis on leaf explants of Oncidium "Gower Ramsey". Plant Growth Regul., 34(2): 229-232.

Islam, M. O. and Ichihashi, S. 1999. Effects of sucrose, maltose and sorbitol on callus growth and plantlet regeneration in Phalaenopsis, Doritaenopsis and Neofinetia. Japan. Soc. Hort. Sci., 68(6): 1124-1131.

Lekha, R. C., Vidya, C., Rajmohan, K. and Mercy, S. T. 2005. Protocorm differentiation and seedling growth in Dendrobium hybrid seed cultures as influenced by organic additives. The Journal of the Orchid Society of India, 19: 67-70.

Minea, M., Piluek, C., Menakani, T. A. and Tantiwiwat, S. 2004. A study on seed germination and seedling development of Spathoglottis kimballiani. Journal of National Academy of Sciences, 38: 141156.

Murashige, I. and Skoog, F. 1962. A revised medium for rapid growth and bioassys with tobacco tissue culture. Plant Physiology, 15: 473-497.

Nasiruddin, K. M., Begum, R. and Yasmin, S. 2003. Protocorm Like Bodies and plantlet regeneration from Dendrobium formosum leaf callus. Asian J. Plant. Sci., 2 (13): 955-957.

Saranjeet, K and Bhutani, K. K. 2012. Organic growth supplement stimulants for in vitro multipl-ication of Cymbidium pendulum (Roxb.) Sw. Hort. Sci. (Prague), 39 (1): 47-52.

Sudeep, R., Rajeevan, P. K., Valasalakumari, P. K. and Geetha, C. K. 1997. Influence of organic supplements on shoot proliferation in Dendrobium. Journal of Horticulture, 3: 38-44. 